\title{
Litter size, effects of maternal body size, and date of birth in South American scorpions (Arachnida: Scorpiones)
}

\author{
Sabrina Outeda-Jorge ${ }^{1}$; Thayná Mello ${ }^{2}$ \& Ricardo Pinto-da-Rocha ${ }^{1}$ \\ ${ }^{1}$ Departamento de Zoologia, Instituto de Biociências, Universidade de São Paulo. Rua do Matão, Travessa 14, 101, \\ 05508-900 São Paulo, São Paulo, Brasil. E-mail: ricrocha@usp.br \\ 2 Estação Ecológica Tupinambás, Instituto Chico Mendes de Conservação da Biodiversidade. Rua Antônio Cândido 214, \\ 11600-000 São Sebastião, São Paulo, Brasil.
}

\begin{abstract}
We present new data on litter size and date of birth (month) for 21 South American scorpions species. We provide data for one katoikogenic species, the liochelid Opisthacanthus cayaporum Vellard, 1932 (offspring = 3; birth month: Jan); and for several apoikogenic species, such as the bothriurids Bothriurus araguayae Vellard, 1934 (53; Sep), $B$. rochensis San Martín, 1965 (22-28; Jan, Aug); the buthids Ananteris balzanii Thorell, 1891 (10-34; Jan-Mar), Physoctonus debilis (Koch, 1840) (2; Sep), Rhopalurus amazonicus Lourenço, 1986 (19; Nov), R. lacrau Lourenço \& Pinto-da-Rocha, 1997 (30; Dec), R. laticauda Thorell, 1876 (41; Nov), R. rochai Borelli, 1910 (11-47; Dec-Jan, Mar-Apr), Tityus bahiensis (Perty, 1833) (4-23; Oct-Mar), T. clathratus Koch, 1844 (8-18; Nov-Jan), T. costatus (Karsch, 1879) (21-25; Jan, Apr), T. kuryi Lourenço, 1997 (4-16; Mar), T. mattogrossensis Borelli, 1901(8-9; May), T. obscurus (Gervais, 1843) (16-31; Jan-Feb, May, Jul), T. serrulatus Lutz \& Mello, 1922 (8-36; Dec, Feb-Apr), T. silvestris Pocock, 1897 (5-14; Dec-Jan, Apr), T. stigmurus (Thorell, 1876) (10-18; Nov, Jan, Mar), Tityus sp. 1 (T. clathratus group - 7-12; Feb-Apr), Tityus sp. 2 (T. bahiensis group - 2; Mar); and the chactid Brotheas sp. (8-21; Jan, Apr). We observed multiple broods: $R$. lacrau (offspring in the $2^{\text {nd }}$ brood $=$ 27), T. kuryi (6-16), T. obscurus (2-32), T. silvestris (8), T. stigmurus (4-9), T. bahiensis (offspring in the $2^{\text {nd }}$ brood $=2-18$; $3^{\text {rd }}$ $=1$ ), and $T$. costatus ( $2^{\text {nd }}$ brood $\left.=18 ; 3^{\text {rd }}=4\right)$. We found statistically significant positive correlation between female size and litter size for $T$. bahiensis and T. silvestris, and nonsignificant correlation for $T$. serrulatus.
\end{abstract}

KEY WORDS. Bothriuridae, Buthidae, Chactidae, Liochelidae, reproductive investment.

Scorpions have many life history traits that are unusual for most terrestrial invertebrates (see reviews in Polis \& Sissom 1990, LOURENÇO 2002a). Scorpions are viviparous contrasting with other Arachnida (Francke 1982b, Polis \& Sissom 1990, LOURENÇO 2002a, Brown 2004). There are two types of embryonic development: apoikogenic and katoikogenic. Oocytes of apoikogenic species develop in ovarian follicules, which are attached directly to the ovariuterus, and are variable in size (small or large) and yolk content (rich or yolkless) (Polis \& Sissom 1990, Farley 2001). Oocytes of katoikogenic species develop in specialized diverticula that branch from the female ovariuterus and are very small and yolkless, as such, the embryos are nourished via an oral feeding apparatus, a specialization of the diverticulum (Polis \& Sissom 1990, FARley 2001). Warburg \& Rosenberg (1996) described a third type of ovariuterus containing yolk-rich ova, in which oocytes apparently mature inside - rather than on the outer surface of - the ovariuterine tubes, forming a single row arranged in the shape of a bead necklace.

Gestation may be quite long, and many scorpion species are iteroparous, that is, capable of repeatedly giving birth after one or more matings (Polis \& Sissom 1990). Some species of buthids are capable to produce multiple (1-5) broods after a single insemination by storing sperm (Piza 1940, Kovoor et al. 1987, Lourenço 2002a, Rouaud et al. 2002). Storage of spermatozoa can greatly increase reproductive potential of the species (Polis \& Sissom 1990, Lourenço 2002a).

Birth usually occurs in protected places, in burrows or under objects (MAURY 1969), and a remarkable similarity of stereotyped behaviors occurs across species (Polis \& Sissom 1990, Lourenço 2002a). Females provide parental care through viviparity (Shaffer \& Formanowicz 1996) and after parturition through at least the first molt of the young (PoLIs \& Sissom 1990, Benton 1991a, b, Peretti 1994, Shaffer \& Formanowicz 1996, LOURENÇO 2002a, BROWN 2004).

Litter size in scorpions is poorly known; from over 1600 extant scorpion species, data are available for about 150 species. However, studies have shown that litter size is quite variable (Francke 1981, Polis \& Sissom 1990, Benton 1991a, b, Lourenço et al. 1996, 2003, Lourenço \& Cuellar 1999, Brown 2001, 2004, Rouaud et al. 2002, LOURENÇo 2002a, 2007). WARBurG (2001) reported that it is difficult to assess the litter size in scorpions owing to the cannibalistic tendencies of the mother during parturition. Maternal cannibalism of stillborns and newborns could provide energy to the female, which nearly does not feed during the gestation period (PeretTi 1994). 
Covariation of reproductive parameters such as egg size and clutch size with body size has been an area of intensive investigation in evolutionary ecology, since reproductive success is maximized, in part, by optimizing the number and size of young (Smith \& Fretwell 1974, Parker \& Begon 1986, Lloyd 1987). Empirical observation has demonstrated that larger females typically produce more and, somewhat less commonly, larger offspring (STEARNS 1992), and theoretical research predicts that clutch size and offspring size should exhibit a tradeoff (Smith \& Fretwell 1974, Stearns 1992).

Because they have more space available to store developing embryos or are better at obtaining, defending, storing, and allocating resources for reproduction, larger females often are predicted to produce more and larger offspring and to have greater reproductive investment (BRown et al. 2003, BRown 2004), and reproductive success (SКоW \& ЈАКов 2003). In most arthropod species, clutch size increases with female body (Fox $\&$ CZESAK 2000), suggesting a fitness advantage of larger females.

In several species of insects, fecundity - the total number of eggs or offspring an animal produces during each reproductive cycle (BEGON et al. 1990) or during the lifespan of a single female (Yoshimura 2003) - of larger individuals is greater than that of smaller ones (Berrigan 1991, PeCKarsky \& Cowan 1991, Honek 1993, Yoshimura 2003). Some studies indicate litter size is often positively correlated with female size in some species of spiders (Marshall \& Gittleman 1994, Simpson 1995, Tanaka 1995, Prenter et al. 1999, Punzo \& Henderson 1999, Brown et al. 2003, Sкоw \& Јаков 2003), and in one species of solifuge (Punzo 1998).

However, studies on reproductive allocation - how much of the available resources to dedicate to reproduction (reproductive investment) and how to allocate that resource fraction into offspring [per-offspring investment (BERNARDO 1996)] - in scorpions are rare (FRANCKE 1981, SMITH 1990, BENTON 1991a, b, Formanowicz \& Shaffer 1993, Brown \& Formanowicz 1995, 1996, Lourenço et al. 1996, 2003, LouRenço \& CLOUdSLEY-Thompson 1999, BROWn 2001, 2004, LOURENÇO 2007). These studies indicate larger females generally produce larger litters and have a greater reproductive investment, although these trends do not hold for all species or even all populations of a single species (Brown 2001, 2004). Moreover, scorpions seem to conform to CongDon's (1989) optimal egg size theory for lizards, which postulates that variation in reproductive output results from variation in number of offspring rather than from differences in egg size (Lourenço et al. 1996, LOUREnço \& CloudsLey-Thompson 1999).

Here, we present data on litter size and date of birth (month) of 21 species of South American scorpions within four families (Bothriuridae, Buthidae, Chactidae, and Liochelidae), in light of new information. In addition, we present new data on deferred fertilization for some Rhopalurus Thorell, 1876 and Tityus Koch, 1836 species. We also analyze statistically the relations between female size and litter size for three scorpion species: Tityus bahiensis (Perty, 1833), T. serrulatus Lutz \& Mello, 1922, and T. silvestris Pocock, 1897 (Buthidae).

\section{MATERIAL AND METHODS}

Scorpions were collected under rocks or while active on the surface at night, using ultraviolet lights in different sites of Brazil, except for Bothriurus rochensis San Martín, 1965 (Bothriuridae) (Fig. 2) ( $\mathrm{N}=2$ ), which were collected in Minas (Uruguai) (MZSP). Brazilian scorpions were: Ananteris balzanii Thorell, 1891 (Buthidae) (Fig. 3) ( $=12)$ São Paulo, Itirapina (Estação Ecológica de Itirapina), Minas Gerais, Januária (Parque Nacional Cavernas do Peruaçu), and Bahia, Ceraíma and Guanambi (MZSP); Bothriurus araguayae Vellard, 1934 (Bothriuridae) $(\mathrm{N}=1)$ Bahia, Ceraíma (MZSP); Brotheas sp. (Chactidae) (Fig. 8) ( $\mathrm{N}=3$ ) Pará, Melgaço (Estação Científica Ferreira Penna) (MZSP and MPEG); Opisthacanthus cayaporum Vellard, 1932 (Liochelidae) (Fig. 1) $(\mathrm{N}=1)$ Tocantins, Palmas (MZSP); Physoctonus debilis (Koch, 1840) (Buthidae) ( $=1$ ) Piauí, Castelo do Piauí (MZSP); Rhopalurus amazonicus Lourenço, 1986 (Buthidae) ( $\mathrm{N}=1$ ) Pará, Alter do Chão (living specimen); R. lacrau Lourenço \& Pinto-da-Rocha, 1997 (Buthidae) $(\mathrm{N}=1)$ Bahia, Itaetê (Lapa do Bode) (MZSP); R. laticauda Thorell, 1876 (Buthidae) (N = 1) Roraima, Bonfim (MZSP); R. rochai Borelli, 1910 (Buthidae) (Fig. 4) $(\mathrm{N}=7)$ Bahia, Santo Inácio, Ceraíma, Guanambi, and Minas Gerais, Janaúba (MZSP); Tityus bahiensis (Perty, 1833) (Buthidae) (Fig. 5) (N=43) São Paulo, Itirapina (Estação Ecológica Itirapina), São Paulo, Praia Grande (Caieiras), Piracicaba, and Guarulhos (MZSP); T. clathratus Koch, 1844 (Buthidae) $(\mathrm{N}=7$ ) Roraima, Bonfim and Amajari (Vila Tapequém) (living specimens); T. costatus (Karsch, 1879) (Buthidae) $(\mathrm{N}=2)$ São Paulo and Espírito Santo, Dores do Rio Preto (MZSP); T. kuryi Lourenço, 1997 (Buthidae) $(\mathrm{N}=2)$ Bahia, Igatu (MZSP); T. mattogrossensis Borelli 1901 (Buthidae) $(\mathrm{N}=2)$ Pernambuco, Goiana (MZSP); $T$. obscurus (Gervais, 1843) [senior synonym of T. paraensis Kraepelin, 1896, according to Lourenço \& Leguin (2008)] (Buthidae) $(\mathrm{N}=5)$ Pará, Melgaço (Estação Científica Ferreira Penna) and Parauapebas (Floresta Nacional de Carajás) (MZSP); T. serrulatus Lutz \& Mello, 1922 (Buthidae) (Fig. 6) ( $\mathrm{N}=11) \mathrm{Ba}-$ hia, Andaraí, Ceraíma, Guanambi, and São Paulo, São Paulo (MZSP); T. silvestris Pocock, 1897 (Buthidae) ( $\mathrm{N}=14$ ) Pará, Melgaço (Estação Científica Ferreira Penna), Chaves (Ilha de Marajó), Alter do Chão, Santarém (Anumã), and Monte Alegre (MZSP); T. stigmurus (Thorell, 1876) (Buthidae) $(\mathrm{N}=3)$ Alagoas, Maceió (MZSP); Tityus sp.1 (clathratus group sensu Lourenço 2002b) (Buthidae) (Fig. 7) (N=7) Minas Gerais, Januária (Parque Nacional Cavernas do Peruaçu) and Goiás, São Domingos (Parque Estadual Terra Ronca) (MZSP); Tityus sp.2 (bahiensis group sensu Lourenço 2002b) (Buthidae) (N = 1) Goiás, Posse (Gruta Rução I) (living specimen). Brotheas sp., Tityus sp.1 and Tityus sp. 2 mentioned above are probably undescribed species.

The animals were kept in laboratory conditions at a mean temperature of $24^{\circ} \mathrm{C}\left(20-28^{\circ} \mathrm{C}\right)$, at the Departamento de Zoologia, Universidade de São Paulo. Each individual was housed in $15 \mathrm{x}$ $15 \times 6 \mathrm{~cm}$ plastic containers, with sand and humid cotton. They were fed crickets Gryllus assimilis (Fabricius, 1775) twice a month, 

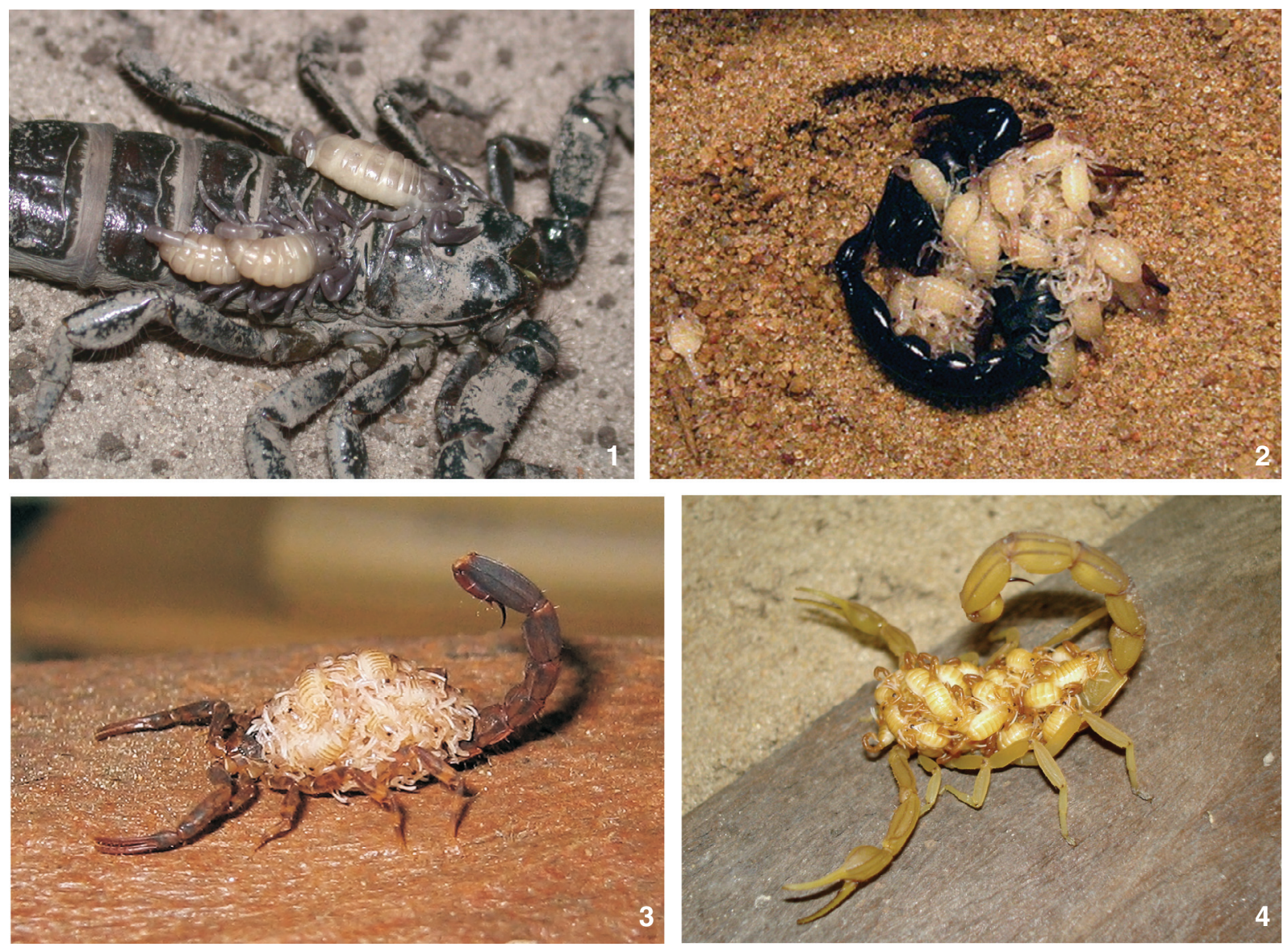

Figures 1-4. Females of four scorpions species carring first instar juveniles: (1) Opisthacanthus cayaporum with 3 juveniles; (2) Bothriurus rochensis with 28 juveniles; (3) Ananteris balzanii with 29 juveniles; (4) Rhopalurus rochai with 33 juveniles. Photographs: 1 by Ricardo Pinto-da-Rocha; 2-4 by Humberto Y. Yamaguti.

except when carrying offspring. Large scorpions were fed with nymph or adult crickets (about $20 \mathrm{~mm}$ total length) and the small ones with young crickets (less than $10 \mathrm{~mm}$ total length).

The containers were checked three times a week for occurrence of birth, presence of newborns, molted instars or dispersed offspring. Most females arrived pregnant from the field. Litter size (number of living and dead juveniles) were counted immediately after newborns were detected. To record litter size, newborns were removed, one by one, from female's dorsum and counted - we returned them to their mother immediately after data collection. The dead ones observed in the containers were counted as well and fixed in 70\% ethanol. All females gave birth in laboratory conditions. Females' carapace length was measured using a dissecting microscope equipped with an optical micrometer.

We analyzed intraspecific relationships between female size and litter size for T. bahiensis, T. serrulatus, and T. silvestris the three species for which we collected sufficient data $(n=35$, $\mathrm{n}=10$, and $\mathrm{n}=9$, respectively), using least-square regression. For the analyses, alpha was set at 0.05. Data analyses were carried out using SPSS for Windows version 14.0.

\section{RESULTS}

We compile data of litter size and date of birth (in month) for 127 females representing 21 species, summarized in table I. We provide for the first time new data on litter size and date of birth for 13 scorpion species within three families, as follows: B. rochensis (Bothriuridae) (Fig. 2), Ananteris balzanii (Fig. 3), Physoctonus debilis, Rhopalurus amazonicus, R. lacrau, R. laticauda, Tityus clathratus, T. costatus, T. kuryi, T. silvestris, Tityus sp. 1 (clathratus group) (Fig. 7), and Tityus sp. 2 (bahiensis group) (Buthidae), and Brotheas sp. (Chactidae) (Fig. 8) (Tab. I).

We observed multiple broods in seven buthid species (Tab. II) probably because of the capacity of some species of buthids to store sperm (Piza 1940, Kovoor et al. 1987, Lourenço 2002a, RouAud et al. 2002). We provide the first record of this phe- 
Table I. Litter size and date of birth (month) of 21 South American scorpions species. New data are in bold and data from literature are

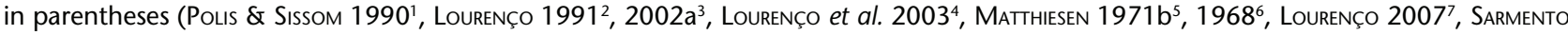

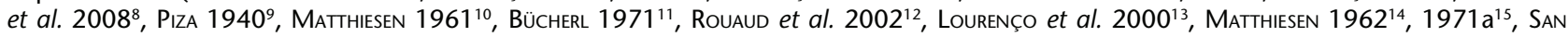
Martín \& Gambardella $1966^{16}$, Aguiar et al. 2008 ${ }^{17}$ ). (CL) Carapace length.

\begin{tabular}{|c|c|c|c|c|c|}
\hline Species by family & $\mathrm{N}$ & Litter size & Date of birth (months) & $\mathrm{CL}(\mathrm{mm})$ & Reference \\
\hline \multicolumn{6}{|l|}{ Katoikogenic } \\
\hline \multicolumn{6}{|l|}{ Liochelidae } \\
\hline Opisthacanthus cayaporum & 1 & $3(15-25)$ & Jan (May-Jul) & 11.50 & $1,2,3,4$ \\
\hline \multicolumn{6}{|l|}{ Apoikogenic } \\
\hline \multicolumn{6}{|l|}{ Bothriuridae } \\
\hline Bothriurus araguayae & 1 & $53(28)$ & Sep (Jul) & 3.80 & 5 \\
\hline B. rochensis & 2 & $22-28$ & Jan and Aug & $3.65 \pm 0.77$ & \\
\hline \multicolumn{6}{|l|}{ Buthidae } \\
\hline Ananteris balzanii & 12 & $10-34$ & Jan-Mar & $3.28 \pm 0.29$ & \\
\hline Physoctonus debilis & 1 & 2 & Sep & 3.30 & \\
\hline Rhopalurus amazonicus & 1 & 19 & Nov & 6.38 & \\
\hline R. lacrau & 1 & 30 & Dec & 4.74 & \\
\hline R. laticauda & 1 & 41 & Nov & & \\
\hline R. rochai & 7 & $11-47(23-55)$ & Dec, Jan, Mar, and Apr (Feb-Mar) & $8.38 \pm 0.66$ & $1,5,6,7,8$ \\
\hline Tityus bahiensis & 43 & $4-23(7-82)$ & Oct-Mar (Jan-Dec) & $6.79 \pm 0.43$ & $1,3,7,9,10,11,12$ \\
\hline T. clathratus & 7 & 8-18 & Nov-Jan & $4.73 \pm 0.23$ & \\
\hline T. costatus & 2 & $21-25$ & Jan and Apr & $7.43 \pm 0.18$ & \\
\hline T. kuryi & 2 & 4-16 & Mar & $7.86 \pm 0.22$ & \\
\hline T. mattogrossensis* & 2 & $8-9(12)$ & May & $4.12 \pm 0.11$ & 7,12 \\
\hline T. obscurus & 5 & $16-31(11-33)$ & Jan, Feb, May, and Jul & $7.90 \pm 1.18$ & $3,5,7,12,13$ \\
\hline T. serrulatus & 11 & $8-36(2-25)$ & Dec, Feb-Apr (Jan-Dec) & $7.34 \pm 0.39$ & $1,7,9,10,12,14,15,16$ \\
\hline T. silvestris & 14 & $5-14$ & Dec, Jan, and Apr & $4.06 \pm 0.40$ & \\
\hline T. stigmurus & 3 & $10-18(6-16)$ & Nov, Jan, and Mar & $6.70 \pm 0.12$ & 17 \\
\hline Tityus sp.1 (clathratus group) & 7 & $7-12$ & Feb-Apr & $3.98 \pm 0.14$ & \\
\hline Tityus sp.2 (bahiensis group) & 1 & 2 & Mar & 6.07 & \\
\hline \multicolumn{6}{|l|}{ Chactidae } \\
\hline Brotheas sp. & 3 & $8-21$ & Jan and Apr & $7.89 \pm 0.73$ & \\
\hline
\end{tabular}

* These individuals present the dentate margins of pedipalp-tibia fingers composed of 16 oblique rows of granules. According to the key to the species of the group T. clathratus (LouRENço 2002b), these correspond to T. mattogrossensis, although T. pusillus Pocock, 1893 is the only species of the group known so far from the state of Pernambuco.

nomenon for the genus Rhopalurus (R. lacrau), and for some Tityus species (T. costatus, T. kuryi, and T. silvestris).

To examine intraspecific relationships between female size and litter size, we obtained data from 35 Tityus bahiensis, $10 \mathrm{~T}$. serrulatus, and nine T. silvestris (Figs 9-11). Tityus bahiensis females gave birth from November to March 2004 to 2008, T. serrulatus from December and February to April 2004 to 2008, and T. silvestris from December 2008 to January 2009. For T. bahiensis, female size was positively correlated to litter size $\left(R^{2}=0.194, F=7.939\right.$, $\mathrm{p}<0.01, \mathrm{n}=35$, litter size: $13.34 \pm 4.12$, carapace length: $6.79 \pm$ $0.43 \mathrm{~mm}$ ) (Fig. 9), being the variation in female size responsible for $19.4 \%$ of the variation in litter size. For T. serrulatus, the relationship between female size and litter size was also positive, but nonsignificant $\left(\mathrm{R}^{2}=0.100, \mathrm{~F}=0.889, \mathrm{p}=0.373, \mathrm{n}=10\right.$, litter size:
$22.40 \pm 8.31$, carapace length: $7.34 \pm 0.39 \mathrm{~mm}$ ) (Fig. 10). For $T$. silvestris, female size was positively correlated to litter size $\left(\mathrm{R}^{2}=\right.$ 0.733, $\mathrm{F}=19.247, \mathrm{p}<0.01, \mathrm{n}=9$, litter size: $9.78 \pm 2.77$, carapace length: $4.08 \pm 0.43 \mathrm{~mm}$ ) (Fig. 11), being the variation in female size responsible for $73.3 \%$ of the variation in litter size.

\section{Litter size}

\section{DISCUSSION}

We observed a small brood size (3) for the katoikogenic O. cayaporum (Liochelidae) (Fig. 1), while Polis \& Sissom (1990), LOURENÇO $(1991,2002 a)$ and LOURENÇO et al. (2003) had reported 15-25. In most arthropods, progeny size decreases with maternal age (Fox \& CZESAK 2000). Decrease of litter size can be observed for females of any scorpion species which arrive to the 

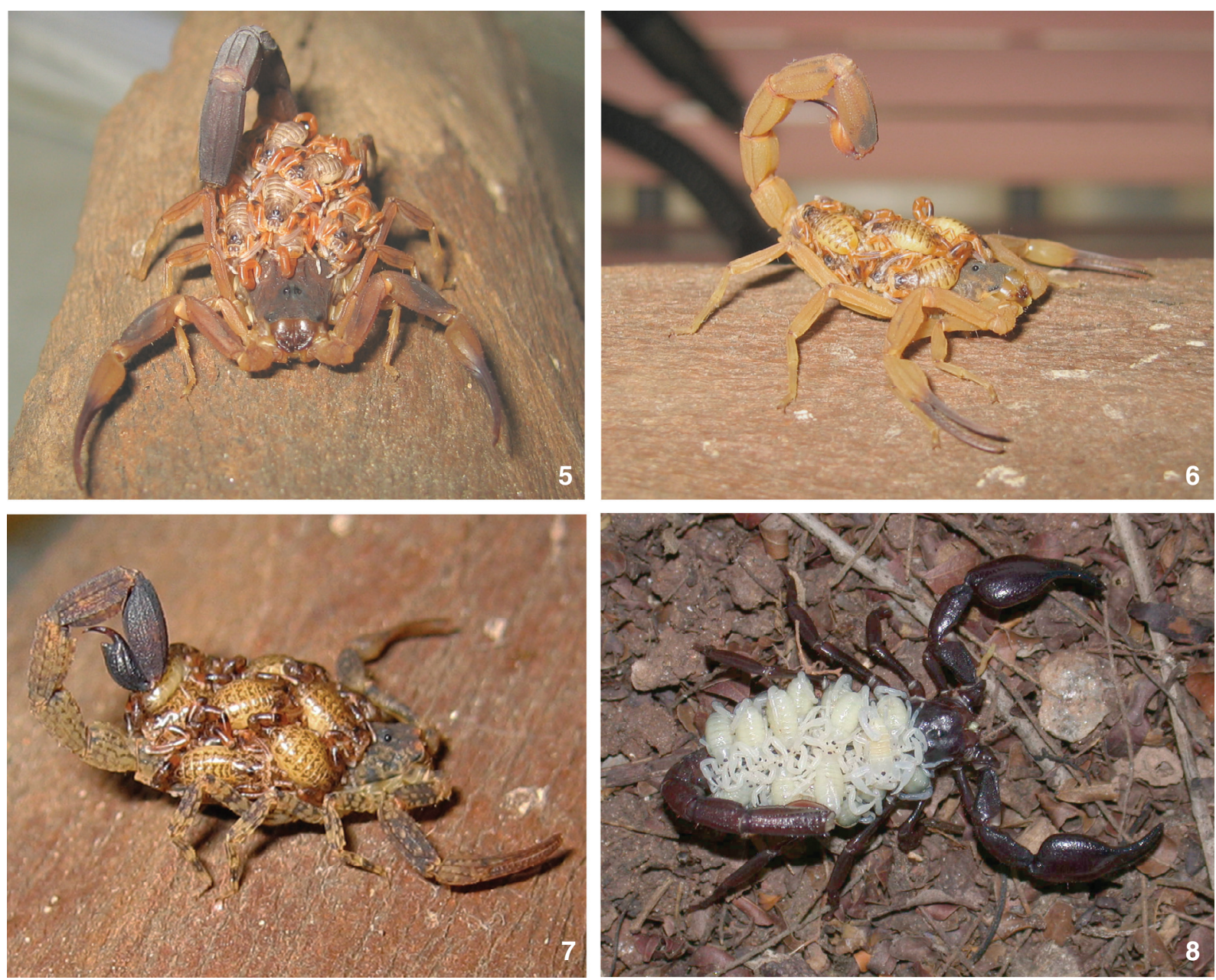

Figures 5-8. Females of four scorpions species carring first instar juveniles: (5) Tityus bahiensis with 17 juveniles; (6) T. serrulatus with 8 juveniles; (7) Tityus sp.1 (T. clathratus group) with 12 juveniles; (8) Brotheas sp. with 21 juveniles. Photographs: 5-7 by Humberto Y. Yamaguti; 8 by Ricardo Pinto-da-Rocha.
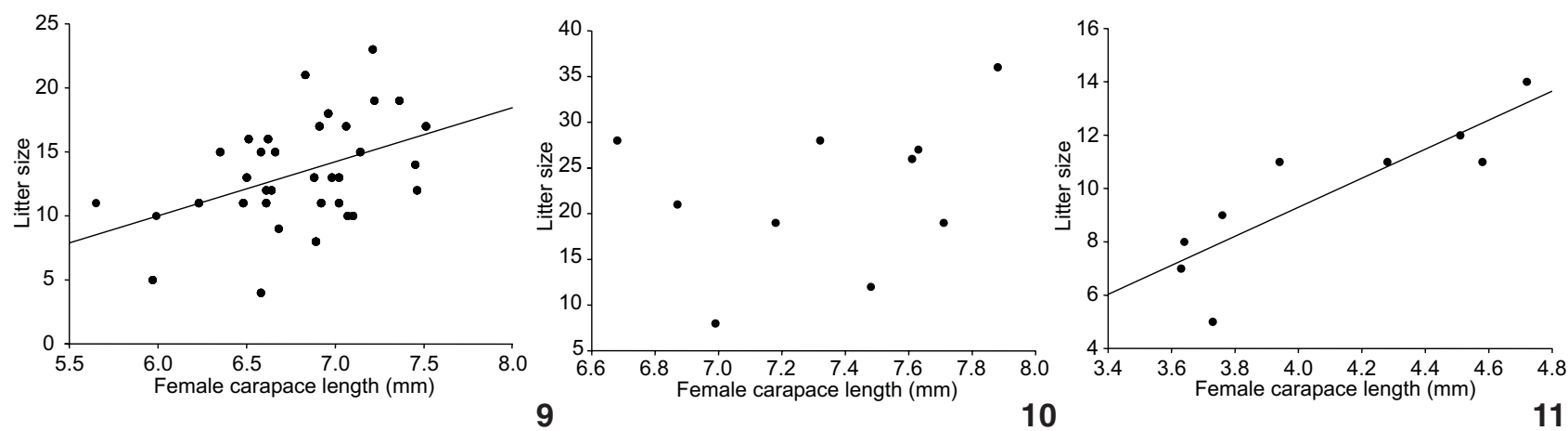

Figures 9-11. Linear regression statistics for the intraspecific relationships between female size (carapace length) and litter size for three Brazilian scorpions: (9) Tityus bahienis $\left(\mathrm{R}^{2}=0.194, \mathrm{~F}=7.939, \mathrm{p}<0.01, \mathrm{n}=35\right.$, litter size: $13.34 \pm 4.12$, carapace length: $6.79 \pm 0.43$ $\mathrm{mm})$; (10) Tityus serrulatus $\left(\mathrm{R}^{2}=0.100, \mathrm{~F}=0.889, \mathrm{p}=0.373, \mathrm{n}=10\right.$, litter size: $22.40 \pm 8.31$, carapace length: $\left.7.34 \pm 0.39 \mathrm{~mm}\right) ;(11)$ Tityus silvestris $\left(\mathrm{R}^{2}=0.733, \mathrm{~F}=19.247, \mathrm{p}<0.01, \mathrm{n}=9\right.$, litter size: $9.78 \pm 2.77$, carapace length: $\left.4.08 \pm 0.43\right)$. 
Table II. Deferred fertilization in South American Buthidae species. New data are in bold.

\begin{tabular}{|c|c|c|c|c|c|c|c|}
\hline \multirow{2}{*}{ Species } & \multirow{2}{*}{$\mathrm{N}$} & \multicolumn{2}{|c|}{$1^{\text {st }}$ brood } & \multicolumn{2}{|c|}{$2^{\text {nd }}$ brood } & \multicolumn{2}{|c|}{$3^{\text {rd }}$ brood } \\
\hline & & Litter size & Date of birth & Litter size & Date of birth & Litter size & Date of birth \\
\hline Rhopalurus lacrau & 1 & 30 & Dec 2006 & 27 & Feb 2008 & - & - \\
\hline \multirow[t]{8}{*}{ Tityus bahiensis } & 8 & 16 & Dec 2001 & 3 & Jan 2003 & - & - \\
\hline & & 11 & Jan 2004 & 10 & Feb 2005 & - & - \\
\hline & & 9 & Feb 2006 & 12 & Jan 2007 & - & - \\
\hline & & 17 & Dec 2006 & 17 & Mar 2007 & - & - \\
\hline & & 21 & Dec 2006 & 18 & Mar 2007 & - & - \\
\hline & & 18 & Dec 2006 & 7 & Mar 2007 & - & - \\
\hline & & 11 & Jan 2007 & 10 & Dec 2007 & 1 & Apr 2008 \\
\hline & & 11 & Dec 2007 & 2 & Nov 2008 & - & \\
\hline T. costatus & 1 & 21 & Apr 2004 & 18 & Nov 2004 & 4 & Mar 2005 \\
\hline \multirow[t]{2}{*}{ T. kuryi } & 2 & 16 & Mar 2007 & 6 & Apr 2008 & - & - \\
\hline & & 4 & Mar 2007 & 16 & May 2008 & - & - \\
\hline \multirow[t]{2}{*}{ T. obscurus } & 2 & 21 & $\operatorname{Jan} 2003$ & 2 & Apr 2003 & - & - \\
\hline & & 31 & Jul 2008 & 32 & Jan 2009 & - & - \\
\hline T. silvestris & 1 & 6 & Jan 2003 & 8 & Jun 2003 & - & - \\
\hline \multirow[t]{2}{*}{ T. stigmurus } & 2 & 18 & $\operatorname{Jan} 2003$ & 4 & Apr 2003 & - & - \\
\hline & & 11 & Nov 2002 & 9 & Feb 2003 & - & - \\
\hline
\end{tabular}

end of their life cycle, when the number of follicles starts to decline (Lourenço 1979, WARburg et al. 1995, WARburg \& Elias $1998 \mathrm{a}, \mathrm{b})$. However, we are not sure whether this is the case we observed since life span of $O$. cayaporum is, in average, seven years (LOURENÇO 2002a, LOURENÇO et al. 2003). As the observed female lived as an adult during four years in our laboratory and gave birth in the first year, we can estimate she was in the middle of her life cycle when she gave birth. Furthermore, katoikogenic embryos may have some greater control over the energy invested in their development than do apoikogenic embryos (Polis \& Sissom 1990), so that the former species might be predicted to produce relatively small litters (BRown 2001).

For Bothriuridae, PeretTi (1997) observed an average number of $32 \pm 1.40$ offspring per parturition and a maximum number between $46-55$ that occurs in $18 \%$ of the cases. Moreover, most of the bothriurid females had similar litter size (VArELA 1961, Maury 1969, 1978, Matthiesen 1971b, Acosta 1983, Polis \& Sissom 1990, Peretti 1997). In our observations, B. araguayae (53 offspring) had larger litter size than reported by MATTHIESEN (1971b - 28 offspring) and most bothriurid species, presenting one of the highest values of litter size for the family, whereas B. rochensis (22-28) (Fig. 2) produced slightly smaller litters than most of the bothriurid species.

LOURENÇO \& CUELLAR (1999) observed an average number in brood of 16 for A. coineaui. Most of the small buthid species show strongly reduced average litter size, in most cases with numbers less than 10 (Rouaud et al. 2002, Lorenço 2007). Thus, A. balzanii (10-34 young) (Fig. 3) produced in average litter size larger than small species of buthids, such as A. coineaui, and most species of Tityus (15-25, see Rouaud et al. 2002).

Matthiesen (1968, 1971b), Polis \& Sissom (1990) and LOURENÇO (2007) reported litter size of 28-49 for $R$. rochai and SARMENTO et al. (2008) reported an average of $35.80 \pm 12.11$ (23$55)$ offspring. Although we observed an average litter size (33 \pm 11.90) (Fig. 4) similar to that presented by SARMENTO et al. (2008), our data (11-47) provide smaller numbers than those published by these authors. When we detected the presence of newborns from this female in particular, four of her 11 offspring were dead. Hence, there could be more stillborns that we did not record due to maternal cannibalism (a behavior unobserved by us) before checking the container. SARMENTO et al. (2008) recorded cannibalism by the female in four out of the five observations.

This is the first record on litter size for T. kuryi (4-16). One particular female gave birth to four offspring, which is much smaller than litter size of most species of Tityus (15-25, see RouAud et al. 2002) and the average number for the order (26, see Polis \& Sissom 1990).

Aguiar et al. 2008 reported litter size of $10.40 \pm 2.90$ (6-16) for T. stigmurus. These authors also observed that litter size and offspring mass were unrelated to female size, although there was significant positive correlation between total litter mass and litter size. Thus, female reproductive resources in T. stigmurus appeared to be applied to the production of more but not heavier offspring. Our data [13 $\pm 4.36(10-18)]$ provide a slightly larger brood sizes than those published by these authors and litter size similar to most species of Tityus (15-25, see RouAud et al. 2002). 
Based on data summarized in Polis \& Sissom (1990), BRown (2001), Lourenço (2002a, 2007), Rouaud et al. (2002), and LOURENÇO et al. (2003), litter size of Tityus species we reported in our laboratory are similar to those published. Closest similarities were found between T. clathratus (8-18), T. mattogrossensis (8-9), T. silvestris (5-14), Tityus sp. 1 (7-12) (Fig. 7), and other species of $T$. clathratus group (12-13).

Within Chactidae, this is the first record for litter size and date of birth for the genus Brotheas (8-21 offspring) (Fig. 8). However, Lourenço et al. (2003) had reported litter size of 14-15 for Chactas lepturus (total length: 50-55 mm) and 15-16 for C. reticulatus (length: $50-60 \mathrm{~mm}$ ). Thus, Brotheas sp. produced larger litter size than both species of the genus Chactas in spite of similar body size.

Furthermore, laboratory-reared individuals often suffer extremely high mortality (90-100\%) (PoLIs \& Sissom 1990), due to stillborns, failure of newborns to detach from the birth membranes or to ascend to female's dorsum, maternal cannibalism, or failure to feed or molt successfully (Piza 1940, STAHNKe 1966, FranCKE 1976, 1979, 1982a, Polis \& Sissom 1990). Maybe the smaller values of litter size observed in the present study, compared to data from literature, is due to a decline of the number of follicles (in the end of the individual life cycle) (LOURENço 1979, WARBURG et al. 1995, Warburg \& Elias 1998a, b), oosorption [known to occur in scorpions (MAURY 1969, WARbURG et al. 1995, WARBURG 2001)], or is the result of maternal cannibalism of stillborns or newborns that failed to ascend to the female's dorsum or - for apoikogenic species - failed to detach from the birth membranes [membranes of katoikogenic species disappear before parturition (FRANCKE 1982b)]. In our laboratory, we have already observed occurrence of abortion (R. agamemnon), stillborns (B. araguayae, $B$. rochensis, $R$. rochai, $T$. bahiensis) and maternal cannibalism of newborns (T. bahiensis), probably due to stress conditions (Fox 1975). Maury (1969) and Peretti (1994) noted that maternal cannibalism increased under stress conditions, especially during birth and newborns. Moreover, Polis \& Farley (1980) and Warburg (2001) reported that it is always possible (probable) that some juveniles have disappeared (by oosorption and/or maternal cannibalism) during the process of parturition, thus the number of juveniles eventually born is considerably smaller. In addition, laboratory conditions might also have been more stressful than in the field, leading to decreased investment in reproduction.

\section{Date of birth}

We provide evidence that the great majority of births occurred during South American warm season, throughout the months of September to April; with most births occurring during the summer (December to March, Tab. I). Opportunistic and synantropic species, such as T. bahiensis and T. serrulatus are able to give birth throughout the year (Polis 1990, Lourenço \& Cuellar 1995, Eickstedt et al. 1996, Lourenço 2002a, Lourenço et al. 2003). Hence, the ability to give birth throughout the year can greatly increase their population in the cities and the number of accidents with humans (LOURENÇo 2002a).

\section{Deferred fertilization}

We observed multiple broods in seven buthid species (Tab. II), including the first record of this phenomenon for the genus Rhopalurus (R. lacrau), and for some Tityus species ( $T$. costatus, T. kuryi, and T. silvestris). We noticed a decrease in litter size through multiples broods, except in T. silvestris, and one case in T. bahiensis and T. kuryi. This could be explained by a reduction on viability of stored spermatozoa, or by the ageing of the female.

Piza (1940), Bücherl (1956), and Matthiesen (1961, 1968) reported the occurrence of storage of spermatozoa in $T$. bahiensis, being 7-20 the number of offspring per female (Matthiesen 1961) and the capability of giving birth to three broods after mating (MATTHIESEN 1968). We observed seven out of eight females giving birth to two broods and one of them gave birth to a third brood, being 1-21 the number of offspring per female. Our data corroborate MATTHIESEN's number of broods and shows a lower number of offspring per female.

Matthiesen (1971b) observed that three females of $T$. obscurus produced multiple (2-3) broods, but he did not mention the number of young born from each parturition. In our observations, two females gave birth to two broods: one female gave birth to 21 and two offspring respectively in the first and second broods, and the other gave birth to 31 and 32 offspring respectively.

Matthiesen (1971b) observed one female of T. stigmurus giving birth to three broods in laboratory, but he did not mention litter size. We observed two females giving birth to two broods, with 4-18 offspring per female.

\section{Parthenogenesis}

Parthenogenesis in T. serrulatus was discovered by Matthiesen (1962). Matthiesen (1971a) reported that T. serrulatus was able to give birth to young up to four times and the average number of offspring per female was 17 . We observed litter size of $21.36 \pm 8.60$ (range $8-36, \mathrm{~N}=11$ ) for $T$. serrulatus (Fig. 6), being similar to MatThiEsen's observations, and four females giving birth to two broods (Tab. III).

Table III. Parthenogenesis in Tityus serrulatus. Four females gave birth to two broods.

\begin{tabular}{lcccccc}
\hline \multirow{2}{*}{ Species } & $N$ & \multicolumn{2}{c}{$1^{\text {st }}$ brood } & & \multicolumn{2}{c}{$2^{\text {nd }}$ brood } \\
\cline { 3 - 3 } \cline { 5 - 6 } \cline { 5 - 6 } T. serrulatus & 4 & 19 & Dec 2006 & & 10 & Dec 2007 \\
& 21 & Feb 2008 & & 14 & Jan 2009 \\
& 28 & Mar 2008 & & 15 & Jan 2009 \\
& 28 & Mar 2008 & & 13 & Jan 2009 \\
\hline
\end{tabular}

\section{Effects of maternal body size on litter size}

In several studies, litter size was shown to be positively correlated with female size (Francke 1981, BENTON 1991a,b, Lourenço et al. 1996, 2003, Brown 2001, 2004, Lourenço 2007). 
We found significant positive correlation between female size and litter size for T. bahiensis ( $\mathrm{p}<0.01, \mathrm{~F}=7.939$ ) (Fig. 9) and $T$. silvestris ( $\mathrm{p}<0.01, \mathrm{~F}=19.247$ ) (Fig. 11). This result is common in other taxa (STEARNs 1992), including insects (HoneK 1993), arachnids - spiders (Punzo \& Henderson 1999) and solifuges (Punzo 1998) -, and other arthropod species (Fox \& CZESAK 2000). Although BRown (2001) found little evidence for the covariation between female size and litter size at the intraspecific level in scorpions, with the increase of research in this area, more evidence has been found to support such prediction (see Brown 2004). Moreover, variation in female size explained $19.4 \%$ of the variation in litter size for T. bahiensis $\left(\mathrm{R}^{2}=0.194\right)$ and $73.3 \%$ for $T$. silvestris $\left(\mathrm{R}^{2}=0.733\right)$. Thus, larger females of $T$. bahiensis and $T$. silvestris produced more offspring (had larger litter) and invested more into reproduction. In addition, larger females have more room to store developing young, that is, if all females obtain sufficient resources for reproduction, then clutch size may be affected by available space within the female for developing offspring (see Bradley 1984, Sinervo \& Licht 1991).

However, correlation between female size and litter size for $T$. serrulatus was nonsignificant ( $\mathrm{p}=0.373$; $\mathrm{F}=0.889)$, although larger females tended to have larger litters (Fig. 10). This trend is common for most scorpion species (BRown 2001, 2004), but WARBURG (2001) reported that larger females do not always produce more embryos; it may be related to the physiological condition of the female, instead of female size.

A second explanation for the lack of correlation between female size and litter size for $T$. serrulatus involves the lower variance in sizes presented by the females in our samples. Alternatively, our sample size is just too small to reveal effects of female size in litter size and further studies should be conducted, although BRown $(2001,2004)$ reported that, among scorpions, sample size is uncorrelated with the magnitude of the correlation coefficient between female size and litter size.

Intraspecific and individual variation in reproduction can be due to other factors besides female size such as foraging success, temperature, humidity, photoperiod, age, and physiological state of the female (see Fischer \& Vasconcellos-Neto 2005). Thus, differences in resource availability and acquisition among females - which can occur if better quality females obtain more or better quality prey - may also explain the trends observed (Brown \& Formanowicz 1995, 1996). Besides, Lourenço et al. (1996) observed that a larger litter could be due to greater food availability and Polis \& Sissom (1990) reported that low food levels might lead females to invest fewer resources in reproduction, or to reabsorb some embryos (Polis \& Sissom 1990). On the other hand, if all females obtain sufficient resources for reproduction, then clutch size may be affected by available space within the female for developing offspring (see BrADLEY 1984, SinERVo \& Licht 1991). Even though females of T. serrulatus were collected in different sites and date, most (50\%) were from two close localities (Bahia State, Ceraíma and Guanambi), and this bias could have influenced our results. Moreover, $T$. serrulatus is partenogenetic and is capable of producing multiple broods during a single year. If litter size changes during the breeding season and the life cycle, then the values used for this species may not accurately reflect the true mean litter size (see Brown 2001). Another factor that may also be involved is that laboratory conditions are more stressful than in the field, and might also have influenced these trends by leading to distinct (decreased) investment in reproduction.

Finally, spatial or temporal variation in the intraspecific relationship between female size and litter size suggests that patterns of resource allocation (to reproduction) are not fixed in a species, but may vary due to genetic differentiation (local adaptation) among populations or due to environmental stochasticity among years (BRown 2001). More information on life histories in other scorpions needs to be gathered to determine the general trend of the correlation between litter size and female size within the order.

\section{ACKNOWLEDGEMENTS}

We thank Humberto Y. Yamaguti for discussion of the manuscript and for making the photos plate. We thank Camilo Mattoni, Dante Pavan, Fabiana Pioker, Felipe F. Curcio, Fernando P.L. Marques, Flávio D. Passos, Humberto Y. Yamaguti, Laura S. Haddad, Marcos R. Hara, Maria E. Bichuette, and Renato S. Recoder, for helping us to collect the material. We thank Fernando P.L. Marques for English review of the manuscript. We thank the laboratory colleagues for helping us. Financial support: CNPq - process \#132743/2007-8 and FAPESP (\#07/529062). Instituto Florestal do Estado de São Paulo and Instituto Brasileiro do Meio Ambiente provided collecting licenses.

\section{LITERATURE CITED}

AcostA, L.E. 1983. Comentarios acerca del estado larval en Bothriuridae (Scorpiones). Historia Natural 3 (23): 196.

Aguiar, A.P.N.; P.L. Santana-Neto; J.R.B. Souza \& C.L.M. AlbuQUerque. 2008. Relationship between litter characteristics and female size in Tityus stigmurus (Scorpiones, Buthidae). The Journal of Arachnology 36: 464-467.

Begon, M.J.; L. Harper \& C.R. Towsend. 1990. Ecology of Individuals, Populations and Communities. Cambridge, Blackwell Scientific, 1068p.

Benton, T.G. 1991a. Reproduction and parental care in the scorpion, Euscorpius flavicaudis. Behavior 117 (1-2): 20-28.

Benton, T.G. 1991b. The life history of Euscorpius flavicaudis (Scorpiones, Chactidae). The Journal of Arachnology 19: 105-110.

Bernardo, J. 1996. The Particular Maternal Effect of Propagule Size, Especially Egg Size: Patterns, Models, Quality of Evidence and Interpretations. American Zoologist 36: 216236.

BERRIGAN, D. 1991. The allometry of egg size and number in insects. Oikos 60 (3): 313-321. 
Bradley, R.A. 1984. The influence of the quantity of food on fecundity in the desert grassland scorpion (Paruroctonus utahensis) (Scorpionida, Vaejovidae): an experimental test. Oecologia 62 (1): 53-56.

Brown, C.A. 2001. Allometry of offspring size and number in scorpions, p. 307-315. In: V. Fet \& P.A. Selden (Eds.). Scorpions 2001: in Memoriam Gary A. Polis. British Arachnological Society, Burnham Beeches, Bucks. XI+404p.

Brown, C.A. 2004. Life Histories of four species of scorpion in three families (Buthidae, Diplocentridae, Vaejovidae) from Arizona and New Mexico. The Journal of Arachnology 32: 193-207.

Brown, C.A. \& D.R. Formanowicz Jr. 1995. Variation in reproductive investment among and within populations of the scorpion Centruroides vittatus. Oecologia 103 (2): 140-147.

Brown, C.A. \& D.R. Formanowicz JR. 1996. Reproductive Investment in Two Species of Scorpion, Vaejovis waueri (Vaejovidae) and Diplocentrus linda (Diplocentridae), from West Texas. Annals of the Entomological Society of America 89 (1): 41-46.

Brown, C.A.; B.M. SANFord \& R.R. Swerdon. 2003. Clutch size and offspring size in the wolf spider Pirata sedentarius (Araneae, Lycosidae). The Journal of Arachnology 31: 285-296.

BücherL, W. 1956. Escorpiões e Escorpionismo no Brasil. V. Observações sôbre o aparelho reprodutor masculino e o acasalamento de Tityus trivittatus e Tityus bahiensis. Memórias do Instituto Butantan 27: 121-155.

BüCHERL, W. 1971. Classification, biology and venom extraction of scorpions, p. 317-347. In: W. BÜCHERL \& E.E. BUCKLEY (Eds). Venomous Animals and their Venoms. New York, Academic Press, 535p.

Congdon, J.D. 1989. Proximate and evolutionary constraints on energy relations of reptiles. Physiological Zoology 62 (2): 356-373.

Eickstedt, V.R.D. von; L.A. Ribeiro; D.M. Candido; M.J. AlbuquerQUE \& M.T. Jorge. 1996. Evolution of Scorpionism by Tityus bahiensis (Perty) and Tityus serrulatus Lutz and Mello and geographical distribution of the two species in the State of São Paulo - Brazil. Journal of Venomous Animals and Toxins 2 (2): 92-105.

FARLEY, R. 2001. Structure, reproduction, and development, p. 13-78. In: P. Brownell \& G. Polis (Eds). Scorpion biology and research. Oxford, Oxford University Press, 431p.

Fischer, M.L. \& J. Vasconcellos-Neto. 2005. Parameters affecting fecundity of Loxosceles intermedia Mello-Leitão 1934. (Araneae, Sicariidae). The Jounal of Arachnology 33: 670-680.

Formanowicz JR, D.R. \& L.R. Shaffer. 1993. Reproductive investment in the scorpion Centruroides vittatus. Oecologia 94 (3): 368-372.

Fox, L.R. 1975. Cannibalism in natural populations. Annual Review of Ecology and Systematics 6: 87-106.

Fox, C.W. \& M.E. CzesaK. 2000. Evolutionary ecology of progeny size in arthropods. Annual Review of Entomology 45: 341-
369.

FRANCKE, O.F. 1976. Observations on the life history of Uroctonus mordax Thorell (Scorpionida, Vaejovidae). Bulletin of the British Arachnology Society 3: 254-260.

FRANCKE, O.F. 1979. Observations on the reproductive biology and life history of Megacormus gertschi Diaz (Scorpiones: Chactidae; Megacorminae). The Journal of Archnology 7: 223-230.

FRANCKE, O.F. 1981. Birth behavior and life history of Diplocentrus spitzeri Stahnke (Scorpiones: Diplocentridae). The Southwestern Naturalist 25 (4): 517-523.

Francke, O.F. 1982a. Birth behavior in Diplocentrus bigbendensis Stahnke (Scorpiones, Diplocentridae). The Journal of Arachnology 10: 157-164.

Francke, O.F. 1982b. Parturition in scorpions (Arachnida, Scorpiones): a review of the ideas. Revue Arachnologique 4: 27-37.

Honek, A. 1993. Intraspecific variation in body size and fecundity in insects: a general relationship. Oikos 66 (3): 483-492.

Kovoor, J.; W.R. Lourenço \& A. Muñoz-Cuevas. 1987. Conservation des spermatozoïdes dans les voies génitales des femelles et biologie de la reproduction des Scorpions (Chélicérates). Comptes Rendus de l'Académie des Sciences, Series 3, 304 (10): 259-264.

LLoyd, D.G. 1987. Selection of offspring size at independence and other size-versus-number strategies. American Naturalist 129 (6): 800-817.

Lourenço, W.R. 1979. La biologie sexuelle et le développement postembryonnaire du Scorpion Buthidae: Tityus trivittatus fasciolatus Pêssoa, 1935. Revista nordestina de Biologia 2 (1-2): 49-96.

Lourenço, W.R. 1991. Opisthacanthus, Genre Gondwanien Defini Comme Groupe Naturel. Caracterisation des SousGenres et des Groupes d'Especies. (Arachnida, Scorpiones, Ischnuridae). Iheringia, Série Zoologia, 71: 5-42.

LOURENÇO, W.R. 2002a. Reproduction in scorpions, with special reference to parthenogenesis. p. 71-85. In: S. TOFT \& N. SCHARFF (Eds). European arachnology 2000. Aarhus, Aarhus University Press, 350p.

Lourenço, W.R. 2002b. Scorpions of Brazil. Paris, Les Éditions de l'If, 307p.

Lourenço, W.R. 2007. Litter Size in Micro-Buthoid Scorpions (Chelicerata, Scorpiones). Boletín Sociedad Entomológica Aragonesa 40: 473-477.

Lourenço, W.R. \& E.A. Leguin. 2008. The true identity fo Scorpio (Atreus) obscurus Gervais, 1843 (Scorpiones, Buthidae). Euscorpius 75: 1-9.

Lourenço, W.R. \& J.L. Cloudsley-Thompson. 1999. Variation in energy spent on reproduction between forest and savanna populations of Pandinus imperator (Koch) (Scorpiones, Scorpionidae) in the Ivory Coast. Bulletin of the British Arachnological Society 11 (4): 136-138. 
Lourenço, W.R. \& O. Cuellar. 1995. Scorpions, scorpionism, life history strategies and parthenogenesis. Journal of Venomous Animals and Toxins 1 (2): 50-64.

Lourenço, W.R. \& O. Cuellar. 1999. A new all-female scorpion and the first probable case of arrhenotoky in scorpions. The Journal of Arachnology 27: 149-153.

Lourenço, W.R.; O. Cuellar \& F.R. Mendez de la Cruz. 1996. Variation of reproductive effort between parthenogenetic and sexual populations of the scorpion Tityus columbianus. Journal of Biogeography 23: 681-686.

Lourenço, W.R.; D. Huber \& J.L. Cloudsley-Thompson. 2000. Notes on the ecology, distribution and postembryonic development of Tityus cambridgei Pocock, 1897 (Scorpiones, Buthidae) from French Guyana and Oriental Amazonia. Entomologische Mittelungen aus dem Zoologische Museum Hamburg 13 (162): 197-203.

Lourenço, W.R.; V. ANDRZEjEWSKi \& J.L. Cloudsley-Thompson. 2003. The Life History of Chactas reticulatus Kraepelin, 1912 (Scorpiones, Chactidae), with a Comparative Analysis of the Reproductive Traits of Three Scorpion Lineages in Relation to Habitat. Zoologischer Anzeiger 242: 63-74.

Marshall, S.D. \& J.L. Gittleman. 1994. Clutch size in spiders: is more better? Functional Ecology 8: 118-124.

Matthiesen, F.A. 1961. Notas sôbre escorpiões. Revista de Agricultura 36 (3): 139-147.

Matthiesen, F.A. 1962. Parthenogenesis in scorpions. Evolution 16 (2): 255-256.

Matthiesen, F.A. 1968. On the Sexual Behaviour of Some Brazilian Scorpions. Revista Brasileira de Pesquisas Médicas e Biológicas 1 (2): 93-96.

Matthiesen, F.A. 1971a. The breeding of Tityus serrulatus Lutz \& Mello, 1927, in captivity (Scorpions, Buthidae). Revista Brasileira de Pesquisas Médicas e Biológicas 4 (4-5): 299-300.

Matthiesen, F.A. 1971b. Observations on four species of Brazilian scorpions in captivity. Revista Brasileira de Pesquisas Médicas e Biológicas 4 (4-5): 301-302.

MaURY, E.A. 1969. Observaciones sobre el ciclo reproductivo de Urophonius brachycentrus (Thorell 1877) (Scorpiones, Bothriuridae). Physis 29 (78): 131-139.

MAURY, E.A. 1978. Escorpiofauna patagónica. II. Urophonius granulatus Pocock 1898 (Bothriuridae). Physis 38 (94): 57-68.

Parker, G.A. \& M. Begon. 1986. Optimal egg size and clutch size, effects of environment and maternal phenotype. American Naturalist 128 (4): 573-592.

Peckarsky, B.L. \& C.A. Cowan. 1991. Consequences of larval intraspecific competition to stonefly growth and fecundity. Oecologia 88 (2): 277-288.

Peretti, A.V. 1994. Comportamiento de relación madre-cría de Tityus trivittatus Kraepelin (Scorpiones, Buthidae). Boletín de la Sociedad de Biología de Concepción 65: 9-21.

Peretti, A.V. 1997. Alternativas de gestación y producción de crías en seis escopiones argentinos (Scorpiones, Buthidae, Bothriuridae). Iheringia, Série Zoologia, 82: 25-32.
PIZA, S. DE T. JR. 1940. Estudos anatômicos em escorpiões brasileiros. Revista de Agricultura 15: 214-228.

Polis, G.A. 1990. Ecology, p. 247-293. In: G.A. Polis (Ed.). The biology of scorpions. California, Stanford University Press, $587 p$.

Polis, G.A. \& R.D. Farley. 1980. Population biology of a desert scorpion: survivorship, microhabitat, and the evolution of a live history strategy. Ecology 61 (3): 620-629.

Polis, G.A. \& W.D. Sissom. 1990. Life history, p. 445-461. In: G.A. Polis (Ed.). The biology of scorpions. California, Stanford University Press, 587p.

Prenter, J.; R.W. Elwood \& W.I. Montgomery. 1999. Sexual size dimorphism and reproductive investment by female spiders: a comparative analysis. Evolution 53 (6): 1987-1994.

Punzo, F. 1998. The natural history and life cycle of the solifuge, Eremobates marathoni Muma and Brookhart (Solifugae: Eremobatidae). Bulletin of the British Arachnological Society 11 (3): 111-118.

Punzo, F. \& L. Henderson. 1999. Aspects of the natural history and behavioral ecology of the tarantula spider, Aphonopelma hentzi (Orthognatha, Theraphosidae). Bulletin of the British Arachnological Society 11 (4): 121-128.

Rouaud, C.; D. Huber \& W.R. Lourenço. 2002. Life history of Caribetityus elli (Armas \& Marcano Fondeur, 1992) from the Dominican Republic (Scorpiones, Buthidae), p. 87-90. In: S. Toft \& N. Scharff (Eds). European arachnology 2000. Aarhus, Aarhus University Press, 350p.

San Martín, P. \& L. Gambardella. 1966. Nueva comprobación de la partenogénesis en Tityus serrulatus Lutz y Mello-Campos 1922. Revista de la Sociedad Entomológica Argentina 28 (1-4): 79-84.

Sarmento, S.M.N.; A.M. Souza; Meiado \& C.M.R. Albuquerque. 2008. Notes on the life history traits of Rhopalurus rochai (Scorpiones, Buthidae) under different feeding regimes. The Journal of Arachnology 36: 476-479.

Shaffer, L.R. \& D.R. Formanowicz Jr. 1996. A cost of viviparity and parental care in scorpions: reduced sprint speed and behavioral compensation. Animal Behaviour 51: 10171024.

Simpson, M.R. 1995. Covariation of spider egg and clutch size: the influence of foraging and parental care. Ecology 76 (3): 795-800.

Sinervo, B. \& P. Licht. 1991. The physiological and hormonal control of clutch size, egg size, and egg shape in Uta stansburiana: constraints on the evolution of lizard life histories. Journal of Experimental Zoology 257 (2): 252-264.

Sкоw, C.D. \& E.M. JАков. 2003. Effects of maternal body size on clutch size and egg weight in a pholcid spider (Holocnemus pluchei). The Journal of Arachnology 31: 305-308.

SмiтH, G.T. 1990. Potencial lifetime fecundity and the factors affecting annual fecundity in Urodacus armatus (Scorpiones, Scorpionidae). The Journal of Arachnology 18: 271-280.

Smith, D.R. \& S.D. Fretwell. 1974. The optimal balance between 
size and number of offspring. American Naturalist 108 (962): 499-506.

STAHNKE, H.L. 1966. Some aspects of scorpion behavior. Bulletin of the Southern California Academy of Sciences 65 (2): 65-80.

Stearns, S.C. 1992. The Evolution of Life Histories. Oxford, Oxford University Press, 262p.

TANAKA, K. 1995. Variation in offspring size within a population of the web-building spider Agelena limbata. Researches in Population Ecology 37 (2): 197-202.

VARELA, J.C. 1961. Gestación, nacimiento y eclosión de Bothriurus bonariensis var. bonariensis (Koch, 1842). Revista de la Facultad de Agronomia, Universidad de la República, Montevideo 19: 225-244.

WARbURG, M.R. 2001. Scorpion reproductive strategies, potencial and longevity: an ecomorphologist's interpretation. p. 349-358. In: V. Fet \& P.A. Selden (Eds). Scorpions 2001: in Memoriam Gary A. Polis. Burnham Beeches, British Arachnological Society, XI+404p.

Warburg, M.R. \& M. Rosenberg. 1996. A different oogenetic pattern in a US apoikogenous scorpion, Vaejovis spinigerus (Scorpiones, Vaejovidae). Tissue and Cell 28: 751-757.

Warburg, M.R. \& R. Elias. 1998a. Differences in the scorpion female reproductive system of Leiurus quinquestriatus $\mathrm{H} \& \mathrm{E}$ (Buthidae), in two populations inhabiting different zoogeographical regions in Israel. Journal of Arid Environments 40: 91-95.

Warburg, M.R. \& R. Elias. 1998b. The reproductive potencial and strategy of Scorpio maurus fuscus (Scorpiones: Scorpionidae); anatomical clues in the ovariuterus. Journal of Zoology 246: 29-37.

WARBURG, M.R.; R.Elias \& M. Rosenberg. 1995. Ovariuterus and oocyte dimensions in the female buthid scorpion, Leiurus quinquestriatus, H. \& E. (Scorpiones, Buthidae), and the effect of higher temperature. Invertebrate Reproduction and Development 27 (1): 21-28.

Yoshimura, M. 2003. Relations of intraspecific variations in fecundity, clutch size, and oviposition frequency to the body size in three species of stoneflies, Sweltsa sp., Isoperla aizuana, and Stavsolus japonicus. Limnology 4: 109-112.

Submitted: 11.VIII.2008; Accepted: 09.III.2009.

Editorial responsibility: Pedro Gnaspini 